Covered in: ERIH PLUS, CEEOL, Index Copernicus, CrossRef, CrossCheck, J-Gate, Google Scholar, Ideas RePeC, Econpapers, Socionet, KVK, WorldCat.

2020, Volume 8, Issue 2, pages: 17-27 | doi: 10.18662/lumenphs/8.2/42

\section{The Factory of False Windows in Law and in Ethics. Symmetries and Dissymmetries of Values}

\section{Jean-Pierre CLÉRO1}

${ }^{1}$ University of Rouen, France, jp.clero@,orange.fr
Abstract: There exists in ethics many values that seem to enjoy full positivity, which is expressed by names, but which in reality hide either asymmetries or false balances between the very opposed values they pretend to reconcile, while this pretense turns out fruitless.

Keywords: Law; ethics; values.

How to cite: Clero, J.P. (2020). The Factory of False Windows in Law and in Ethics. Symmetries and Dissymmetries of Values. Logos Universality Mentality Education Novelty: Philosophy \& Humanistic Sciences, 8(2), 17-27. doi: https://doi.org/10.18662/lumenphs/8.2/42 
The Factory of False Windows in Law and in Ethics. Symmetries and ... Jean-Pierre CLÉRO

There exists in ethics many values that seem to enjoy full positivity, which is expressed by names, but which in reality hide either asymmetries or false balances between the very opposed values they pretend to reconcile, while this pretense turns out fruitless.

Such is the case of three sorts of values that we want to study specifically: secularity, tolerance and dignity.

In promoting secularity and tolerance, the State intends to keep in each other's presence values opposing to a point of irreducible conflict, and to unite in a same community the persons who support them. It succeeds in doing so by pretending to adopt an intermediate philosophy that, as Rawls said, does not imply any metaphysical position » (Rawls, 1991, p. 249); - a little farther, Rawls returns to the charge with the same argument (Rawls, 1991, p. 250) - in other words, this philosophy may be adopted by any citizen, whatever his or her own values. But this neutrality is evidently a counterfeit: it does not and cannot exist. Any value affirms positions of existence. If, in the name of secularity, the State imposes values, these values enter the game of powers with the others and must debate with them. We cannot say that they resolve their conflict, simply because there is no such thing as philosophy that makes everyone agree, provided they be in good faith; leaving aside all the others taxed in bad faith under pretense that they would refuse such a deal. Nothing is simpler for a man that displays a certain ethical nihilism than accepting these intermediate values; nothing is more difficult, on the contrary, than doing the same for these that have strong values whose requirements are well defined. Similarly to the effort of secularity, the effort of tolerance appears to be greater for some than others: should one accept this situation and stand by it? Or should this inequity of effort among citizens be taken into account? However, how to get there when it seems that the systems of separation of churches and State, of beliefs from their acting out, are starting to show their limits? Would it not be possible to get out the intermediate values of hypocrisy in radically changing the essence of the law and the nature of our relation to law?

If secularity and tolerance generally raise similar issues, dignity poses different problems. Dignity affirms that every human being -and without a doubt every animal- has the right to be respected. But first, under the abstract and steady label of dignity, society is satisfied with a dynamic set of compensations - we began to analyze this point in Clero (2020) -, man can mistreat men and disregard their dignity without their dignity being affected if those who are mistreated react with dignity to their mistreatment. Second, a racist, sexist, unequal behavior may persist alongside an affirmation of dignity if we are convinced that the individuals we mistreat are inferior to the 
men entitled to discuss dignity. Such is the case of David Hume who, although he is the author of a great discourse On the dignity of human nature (the essay was published in the edition of 1741 and it was modified in editions after 1768 when its title became: On the Dignity or Meanness of Human Nature) -of which he supports the value even in its illusions: «I must, however, be of opinion, that the sentiments of those who are inclined to think favorably of mankind, are more advantageous to virtue than he country principles, which give us a mean opinion of our nature» (Hume, 1963 , p. 82) -, displays without any embarrassment his racism against blacks (the most racist of his notes accompanies the essay On National Characters published in 1753) (Hume, 1753), even when the evidence is given to him that a worthy successor to Newton, at Cambridge, can have black skin. It is the case of Francis Williams (the note will be slightly modified in 1777; its reference to the mathematician further aggravates the racism it already contained). The problem is not that of dignity, but it is to know who may benefit from it and on what to trigger the notion. Let's not forget that it took more than fifty years after the Declaration of human and citizen rights for the French Republic to abolish slavery (we must wait until April 27, 1848, for the temporary government of the Second Republic to sign the second decree of the abolition of slavery, under the impulse of V. Schoelcher): during all this time interval, the contradiction did not seem so exorbitant to most people who lived in the first half of the XIX ${ }^{\text {th }}$ century. Society can feel self-righteous by highlighting such values as dignity and yet by putting up with what we view as amazing contradictions. These contradictions can function durably, so long as none of those implementing them notices. Thoughtlessness is a condition for the proper functioning of values - Hume makes the relative obscurity of the origin of governments an advantage upon the pseudo-light that " contractualist " theories claim to do in politic questions; the habit to obey without asking more questions remains the best foundation of politics (Hume, 1896, p. 558).

By selecting these three values, we do not mean they are the only ones likely to fulfill the definition of dissymmetries and false balance, more or less hidden under names; what is done in a very different way depending on the language. The present analysis could be extended to many other values like respect or ethical behavior like consent. We only expect to show that, in a very large number of cases, values which their supporters take care to let appear well-balanced are really underpinned by imbalances, denied with such a success that even very wise philosophers get caught up in them and keep only one side of the notions they use. 
The Factory of False Windows in Law and in Ethics. Symmetries and ... Jean-Pierre CLÉRO

Dignity is relative to shame. Somebody is undignified who displays a shameful behavior without feeling the slightest touch of shame, or who knows how to prevent shame, how to curb it and circumvent the beginnings of shame. One can keep dignity whereas one is treated shamefully. Shame is everywhere as a ghost. Such is the point Sartre forgot: he describes shame as one of the most acute feelings, one of the most painful, the feeling that makes us feel the best our existence for others (Sartre, 1943, pp. 275-277). But shame may be involved in situations where it never occurs as an experienced feeling; in any case, not in another form than that of a "representant » of shame which stands for it. Shame may be an affect that one of the agents of the situation is waiting from another as what should be felt, at the place and the role she is in; but that this «other» does not necessarily feel and even does not dream of feeling at all. Whomever sees him/her act like this fancies that he/she would feel ashamed if he/she were in his/her place; but nothing can prove it. So, in such circumstance -and it is not the only one-, an affect, though felt by nobody, precisely because of its absence itself, and being never where it is expected, is able to saturate all the positions of a situation. I can say, before an act that loathes me, «It's a shame » or "It's shameful »: I do not feel the slightest attack of shame and I do not wait for anybody to feel it. What is real in this affect is less to be felt than the necessity to be situated in relation to this affect, than the fact to treat it as a money, or to make it circulate incessantly, like the words in a language. Not to be in a position to have this feeling; or only by delegation, in place of others: such is the rule. The "shamefulness » is the indication of the place where shame should be felt; the fact that it is not felt being precisely a constituent of what is «shameful ». If Sartre has written the phenomenology of the vivid Erlebnis of « shame» (Sartre, 1943, p. 275), Aristotle analyzed the «shamefulness » in a chiseled way (Sartre, Rhetoric, n.d.). If «shame » and "shameful » seem the closest possible terms, the modes of being they designate are the most distant; "shameful » being something to have constantly a strategy towards shame, "shame» being the affect likely to burst beyond all strategy and reducing it to nothing.

Several times, we will have heard the term «place»: «to be in place », «to take place », etc. The game of dignity, which is that of «shame » and "shamefulness ", is deeply that of sympathy, understood in the sense of Hume (1986) and Smith (the two first chapters of the Theory of Moral Sentiments are about sympathy; the chapter IV of the first Part deals with the same subject),(Smith, 1759) later criticized by Bentham (the criticism of sympathy, as it is conducted in the Deontology, in the chapter about The Table of the Springs of Action, amounts to depriving sympathy of its disinterested 
dimension and to establishing that the imagination we project ourselves into others is not forcibly contradictory with egoism and self-regard; in the marginal notes of The Table of the Springs of Action, one can consult in particular \$S 75, 139, 354, 355) (Bentham, 1983). Through sympathy, we believe we are in unison with each other, whatever he/she be in a position to abuse or be abused, with what he/she experiences, situated as he/she is, with what he/she should feel. In reality, this unison is never obtained, not even the slightest sketch. Only, an affective image arises, that we take for an affect and that we imagine being able to accommodate in the place occupied by the other. So, there is a forgery of the sympathy; Hume knows it very well without denying its social usefulness. A. Smith believes that he could go further, in showing that the affect we assign to another was less a copy than some sort of resolution to the situation - so, when we see an angry man, we sympathize less easily with him than with his potential victims: "nous sommes immédiatement disposés à prendre parti contre celui qui paraît les mettre tellement en danger » (Smith, 1759) (an imaginary social rebalancing takes place through sympathy). If, for instance, in a given situation, somebody does not seem to feel the affect he should experience, everything happens as if I felt it in his place, and so as if I restored a compromised balance in the relations I witness. However, we must be careful: the fake window I build for this restoration remains a false one until the end and corrects nothing but seemingly (Hobbes had made it a feature of fiction) (Hobbes, 1983, p. 312). Nobody knows, except myself, what I have in mind when I «replace» the affect that the other seems to experience and with which he should not be content with another affect that I produce by myself and that seems counterbalance the clear deficit I am witnessing. But this deficit remains in place without anything effectively moving. The decision to substitute is nothing but fictitious. And yet, without the world being changed, except through the idea I have of it, I recover some trust in this world it would have been easy to lose. Sympathy is a fabric of false windows that allows to bear the reality by pretending to transform it, to counterbalance its injuries for example, without really changing anything. That does not mean that nothing should ever be changed; but that there are fictitious changes which, in many situations, are sufficient.

Let's move on to the functioning of secularity and tolerance that let the State develop a philosophy which refuses to be treated as one philosophy among others -what it is really- but pretends to be the ordinary philosophy of people of good faith, almost without them knowing it. A philosophy that fades away so that, once the other ideologies, dogmas, moral tenets have been reduced to the same denominator, the State can pretend to 
The Factory of False Windows in Law and in Ethics. Symmetries and ... Jean-Pierre CLÉRO

claim not to pursue other goals than that to allow everyone -whatever their religious options- to live in harmony with others for reasons that are not those of their options; but also in a way such that a return cannot be made so that the State would be obliged to explain oneself to spokespersons of ideologies, religions, morals, of which it wants to prevent the acts, if not to silence the speeches and the writings. This treatment of the tolerance is that of Locke; it is also that of Spinoza. In the Republic of Spinoza, « chacun peut penser et juger sans la moindre restriction - et par conséquent aussi parler, pourvu qu'il se contente seulement de parler et d'enseigner, et qu'il défende ses thèses par la seule raison, et non pas par la ruse, la colère et la haine, ou avec l'intention d'introduire quelque nouveauté dans la république par l'autorité de son décret » (Spinoza, 1999, pp. 633-639).

However, the treatment of tolerance and secularization by scissions and cuts has its limits - We have attempted to show that in an article written under the title "Éthique et religions. Critique d'une séparation » (Clero, 2020b). The separation of the cases on which the State must rule from those on which it lets the Churches rule is much less simple than it seems, and several problems make this cut illusory. Moreover, the ordinary way the State demands to every citizen to make a cut between their thinking, talking, teaching and what it is doing, between the symbolic and the acting out, is equally illusory. Each citizen is split between contradictory demands; some of them - because of an ordinary nihilism (we mean by "nihilism » the attitude and doctrine that consist in believing in no value whatever) - have less to suffer from the split than others; the only instance that is not split being the sovereignty of State who has the monopoly of real action and tries to make people forget it rather than to face unequal treatment: The State subjects its citizens -in fact, a number of them- to a regime from which it excepts itself. Begun under the auspices of Locke, the solution of tolerance and secularization problems becomes early Hobbesian; Hobbes had the merit to speak frankly - we have shown this point in our article, quoted above (Clero, 2020b).

Can it be otherwise? Probably yes if one abandons a contract conception of the State, of the law, and of many other ethical designs which work on the same model. Bentham's reader is often surprised by the unexpected amalgamations of the author that treats in the same way a thinker who gives an important role to sympathy, moral sense or common sense, and a «contractualist» who hardly uses sympathy or moral sense. At first glance, this classification seems expeditious. One example of it may be found in the Introduction to the Principles of Morals and Legislation, chap. II. In an other instance, he divides the principles according to the principle 
of utility and the others that are " making war upon pleasures » (Bentham, 1907). The reason is that all these intellectual attitudes pretend to be able to count on the agreement of another, of any other, provided he/she be of good faith. The height of these attitudes is reached by «contractualists » which cannot hide disagreements between citizens, but imagine they can compensate for them by laying, behind the contract that cannot clear them, another agreement, supposed able to blur them: unanimously, we would assume that majority rule erases differences and makes that my true will is the general will, even though I would disagree with it (the position of Rousseau will have been recognized; the auto warrants the value of the summation of citizens' opinions, necessary sundry and contradictory, by the underlying " general will » which is the deepest I of every citizen). Is this hypocrisy, that we called « fabric of false windows », inevitable? Can I agree to abstain from values that seem to me the most essential ones? Or can I accept, if I am not personally convinced by essential values, that others are forced to abstain, being " forced to be free », according to the famous phrase of the Contrat Social? (Rousseau, 1964, p. 364). The ideological erasure of disagreements does not forcibly strike me as a good thing; it creates very unequal citizens, what makes them unhappy, and others, witnesses of these inequalities, what make them equally unhappy.

It may be that Bentham's definition of the law (Bentham, 1970; 2010 , p. 24), that deals exactly with the question of adherence to the law, contains some components of the solution. The squared "as" only appears in Of Law in General: "A law may be defined [as] an assemblage of signs declarative of a volition conceived or adopted by the sovereign in a state, concerning the conduct to be observed in a certain case by a certain person or class of persons, who in the case in question are, or are supposed to be, subject to his power: such volition trusting for its accomplishment to the expectation of certain events which it is intended such declaration should upon occasion be a means of bringing to pass, and the prospect of which it is intended should act as a motive upon those whose conduct is in question ». Such a conception of the law entails not only that a good citizen must obey law punctually, but also that he has the right to censure it freely (Bentham, 1977, p. 24). Force of the law is made up of an entanglement of adherences and reluctances; as long as adherences outweigh reluctancies, even resistances, the text of the law is the law; however, every citizen must realize and conveniently remember that the law to which he adheres is not accepted by everyone, but that everyone submits to law as long as the interplay of forces is favorable to adherences. This way of thinking the efficiency of the law -rather than its ideal strength obtained by contract- 
should inspire our attitude toward sympathy, common sense, moral sense; without going to rejection, which is often impossible, this attitude should not hold phantasms of intersubjectivity as realities upon which we can rest. The desire takes often intersubjectivity for reality; it is indeed a constitutive illusion of society but in which we must not indulge unsuspectingly.

Will it be claimed that Bentham's definition of the law conceals a contract, as the contract disguises conflicts in unanimity? Certainly not, for the Sovereignty that relies on the loyalty and trust of a majority for such and such a law is less of a contractualist nature, like in Hobbes, Locke and Rousseau, than it depends on the habit of obedience. Like Hume, Bentham considers that the habit of obedience is the real foundation of the power of the Sovereign: "The only thing that gives the sovereign body the power it possesses is the habit of submission » (Bentham, 2016, p. 180).

However, let us not believe that the «probabilistic » and «statistical» conception that we forward as a constituent of the law and of the adherence to the law is a perfect and definitive solution even if it has advantages over contractualist solutions. We would like to show finally that the first probability calculations which are unanimous among mathematicians are not, despite their rigor, deprived of dissymmetries. The values that initiate the questions of partition, from which the probability problems started, were quite in the order of the search of equity -what is prima facie weird to establish mathematical reasonings that seem so foreign to this kind of values- but moreover they were defended in astonishing conditions of inequality.

The problem that, about 1650, gave rise to the calculus of probabilities is very simple - Pascal has called it «le problème des partis »; the meaning of " partis » being that of "division »; all the " oeuvres complètes "<Complete Works> of Pascal provide the texts where the problem was played out and solved (Pascal, 1954, pp. 75-129) - : two players -there can be more- play a game of chance by bringing the same amount at the start. They set the number $\mathrm{N}$ of winning parts to be reached by a player that will be the winner and will take away the stake. But an incident interrupts the game before a winner can be determined according to the rule: how to partake the stake?

One could imagine that there is, to this problem, one objective solution that suits all players and that it is easy for them to agree on by adopting an imaginary intersubjective point of view. One quickly realizes that this is not the case by noticing a little sign in the exposure that Pascal gave to solve the problem. 
That solution is strangely linked to a kind of advocacy plea from the player who was in the best position to win rather than to the discourse of a judge. Pascal makes this player speak first and it is important that he be the first to attempt to convince: it is not simply a rhetorical device.

Admittedly, the loser could speak the same language than the winner or his/her spokesperson; it would be indeed possible but it would be also inhuman.

As amazing as it sounds, the discourse of probabilities and expectation is not an egalitarian discourse. Certainly, at the beginning, partners are equally engaged in the game: but, from the first part played, the equality is broken, and, as the game progresses, some players are in a better position than others to win. The one who is winning is also, at least ideally, in a better position than others to consider the conditions required to solve the problem posed by the interrupted play, because he has the most interest in safeguarding these conditions.

The winning player intervenes so that the problem cannot be concealed by the loser; so that the parts already played remain true parts which, when they were played, engaged the real, as every player believed it when he was playing them. That must be respected.

Speaking first or speaking second is of utmost importance. Everyone engages in a struggle to give to their advantages the reality they need.

How is it possible that it is through a biased discourse that the problem of division may be solved? How it may be that biased advocacy in favor of the winning player delivers the solution? We know the card advanced by the winner: in reasoning about the next part, he begins to put things at the worst for him; he takes for granted what the worst things give him; and he divides the rest in two, in case there are two players.

So, if, to be the winner, one of the two players had one part left to play and if $\mathrm{S}$ is the global stake, he could demand to his partner: $\mathrm{S} / 2+1 / 2$ $(\mathrm{S} / 2)=3 / 4 \mathrm{~S}$.

And, if, to be the winner, one of the players had two parts left to play, he could demand to the partner who has one part behind the other: $3 / 4 \mathrm{~S}+1 / 2(\mathrm{~S} / 4)=7 / 8 \mathrm{~S}$.

If the winner had three parts left to play, he could demand to the partner who is partly behind the winner: $7 / 8 \mathrm{~S}+1 / 2(\mathrm{~S} / 8)=15 / 16 \mathrm{~S}$.

Etc.

The weight of the discussion relates to the following part whose importance seems disproportionately overestimated, whereas it is as virtual as the other parts. We could estimate that the winning player asks for too much: would it not be possible to make an average of the parts that remain 
to be won, be $2 / 3$ for one player and $1 / 3$ for the other? The loser would get $1 / 3$ of the stake; is it not what he would plead if he spoke first? By the « overestimation » of the following part, he has no more than $1 / 4$ of the stake. To tell the truth, the Pascalian solution is founded, not on an average, but on the order of parts. The position of the winning player allows to realize that at best, and to make defensible what seems to be an exorbitant advantage. The player who is losing with two parts late relatively to the agreed term of the game, whereas the winning player has only one part late, has not one in three chance of winning, but only one in four.

What is ethically lame, by appearing to benefit the winning player, may turn out to be a fair calculation. Is it right that the winning player should risk to the aid of his interest? Probably yes, for if he did not it, there would not be a fair share. As soon as he wants us to take his interests into account, the matter is to assert them in terms of actual chances of winning.

So, what we have called the dissymmetries of the game of the values affects the mathematics on which we could have thought it would be possible to count in order to enjoy a stable position which makes it possible to record dissymmetries.

What is truly "astounding " - in French, "stupéfiant » is the word that has been retained by Pascal to qualify his calculation that goes through the consideration of parts which will never be played in order to determine how much we really owe each playser (Pascal, 1954, p. 1403) - is that, to measure real amounts, we are obliged to consider situations which we certainly know will never happen, because we will not play them; these situations could have happened but without the players being aware of them.

Our work -of which we will only present one aspect- may be qualified as meta-ethical. It consists of being vigilant about dissymmetries, false symmetries, "false windows », that circulate underneath and through values rendered deceptively stable because they are designated by nominal entities. Let us not believe that this work merely holds theoretical reach: its practical value is to denounce as fallacies the dissymmetries described above. However, we must pay attention to the fact that a critical or conceptual work, though it must overcome immediate appreciations, cannot be substituted to them without care. It is not impossible that -if we set aside, in order to fight them, the perverse games of racism, sexism, colonialism, economic inequalities-, it may be necessary to grant some unconscious leeway to values in order to keep a tension between those values as they appear along with their production which follows quite another logic. 


\section{References}

Bentham J. (2016). Preparatory Principles. Clarendon Press.

Bentham, J. (1907). Introduction to the Principles of Morals and Legislation. Claredon Press.

Bentham, J. (1970). Of Laws in General. University of London, The Athlone Press.

Bentham, J. (1977). A Comment on the Commentaries. A fragment on Government. The Athlone Press. p. 399)

Bentham, J. (1983). Deontology. Oxford University Press.

Bentham, J. (2010). Of the Limits of the Penal Branch of Jurisprudence. Clarendon Press, Oxford.

Clero, J.P. (2020a). L'Éthique ne saurait se passer d'un souci du langage. Le cas singulier de la dignité, [Ethics cannot do without a concern for language. The case of dignity]. Etbics, Medicine and Public Health; Ethique, Médecine en Santé publique, 14, 100521. https://doi.org/10.1016/j.jemep.2020.100521

Clero, J.P. (2020b). Critique d'une séparation. Revue Française d'Éthique appliquée, 9, 117-128.

Hobbes, T. (1983). Léviathan. Sirey.

Hume, D. (1753). On National Characters.

Hume, D. (1896). A Treatise of human nature, Book III, Part. II, sec. X. Clarendon Press. p. 558

Hume, D. (1963). Essays moral, political and literary. Oxford University Press. p. 82)

Pascal, B. (1954). Oenures complètes. Bib. de la Pléiade. 1954, p. 75-129.

Rawls, J. (1991). Théorie de la justice. Éd. du Seuil. p. 249

Rousseau, J.J. (1964). On le forcera d'être libre, [He will be forced to be free]. In: J.J. Rousseau, Oeuvres complètes, Tome III. Bib. de la Pléiade, Gallimard.

Sartre, J.P. (1943). L'Être et le Néant, III'rd Part., Chap. I. Gallimard. p. 275-277

Sartre, J.P. (n.d.). Rhetoric, II ${ }^{d}$ Book, 1383b-1385a.

Smith, A. (1759). Theory of Moral sentiments.

Spinoza, B. (1999). Traité Théologico-politique. PUF. 